新開発の全アルミ合金の超高真空装置

$$
\begin{gathered}
\text { 高エネルギー物理学研究所 } \\
\text { 石 丸 肇 }
\end{gathered}
$$

( 1982 年 8 月 10 日受理)

\title{
New all aluminum alloy ultrahigh vacuum system
}

\author{
Hajime Ishimaru
}

(Received August 10, 1982)

\begin{abstract}
Suitable aluminum alloy flange/ gasket/ bolt, nut and washer combinations, vacuum chambers, bellows, feedthroughs, windows, sputter ion pumps, metal valves and related aluminum alloy vacuum components are developed for the TRISTAN electron-positron storage accelerator in National Lab. for High Energy Physics Japan. Aluminum alloy are preferred as a material for the ultrahigh vacuum system of large storage accelerator and fusion machine because of its extremely low radioactivity and extremely low outgassing rate.
\end{abstract}

\section{$\S 1$. 序}

高エネルギー物理学研究所においてトリスタン計画が昨年 4 月から正式にスタートし, 現在入 射蓄積リングを建設中である。 トリー, 略してPF] の $2.5 \mathrm{GeV}$ の電子を入射させる。並行して 57 年度から主リングの建設 が始まり既に基本設計を完了し，現在詳細設計を進めている。［図1]にトリスタン計画のレイ アウトを示す。

トリスタン計画の開発研究において世界初の全てアルミニウム合金の超高真空システムを完成 させ，現在建設中の入射蓄積リングに応用している。 ${ }^{2}$ 全てアルミニウム合金の開発の発端は約

National Laboratory for High Energy Physics, Oho-machi, Tsukuba-gun, Ibaraki-ken, 305, Japan 


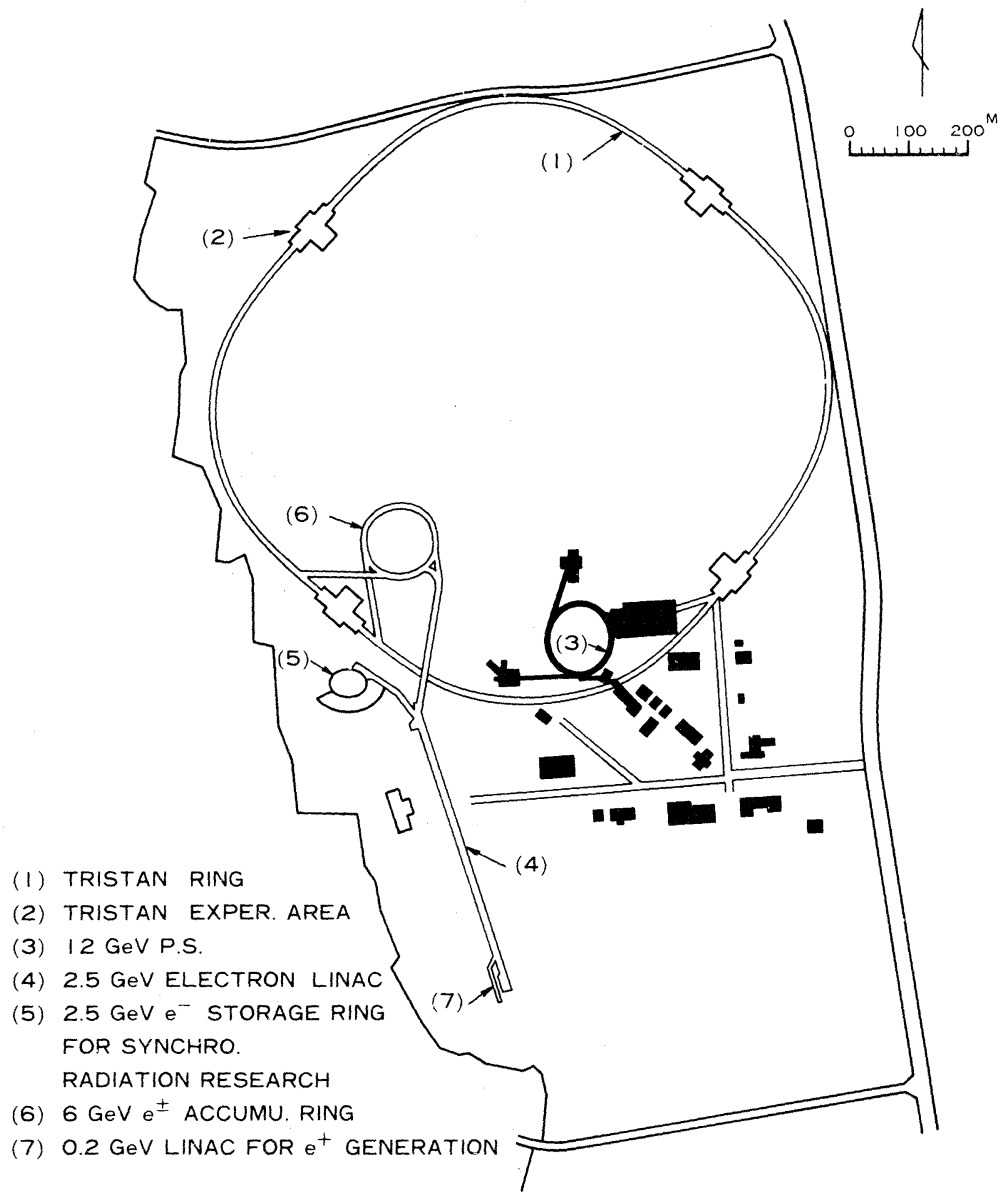

第1図トリスタン計画のレイアウト。

6 年前筆者兮陽子シンクロトロンのビーム計測を研究対象としていた時に残留放射能による被爆 を低減させたいと考えたととであった。ビーム計測で成果を出そうとすれば真空チェンバーの内 部に組込んだ検出器を改善したくなる。ステンレス鍋の真空チェンバーのフランジを取外し，内 部の検出器を交換し再びフランジを取付ける作業を行うと1回の作業で多い場合は許容量に達 する被爆になるてとがあった。汎用金属で残留放射能の低減に寄与出来るものがあるのではない かという素朴な疑問から, アルミニウム, ステンレス鋼, 鉄, 銅, 黄銅の5 種類を同一寸法 $\left[1^{\mathrm{t}}\right.$ $\times 50^{\mathrm{mm}} \times 50^{\mathrm{mm}}$ ]に切断し重ね合わせて当時ビーム損失の最も大きい部分のベローズの上に 放置しておき，運転停止後サンプルを取出し放射能の強さの経過を測定してみた。結果は[図 2 ] 
新開発の全アル之合金の超高真空装置

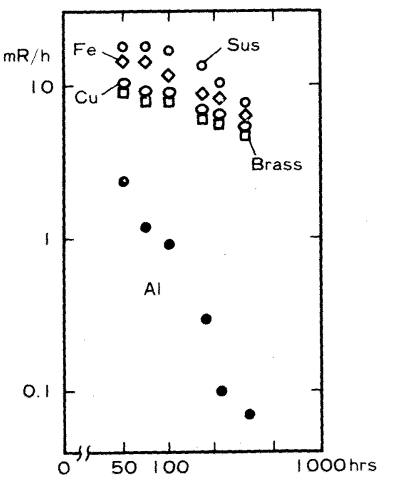

第2図 アルミニウム，ステン レス鋼, 鉄, 銅, 黄銅 の 5 種の金属の $8 \mathrm{GeV}$ 陽子ビーム照射による 残留放射能の時間変化。

に示されるようにアルえニウムだけが枌違いに早く減衰するとと を見出した。 ${ }^{3}$ ） 乙の時から加速器の真空装置をアルミニウム化す る研究が始まった。

現在では加速器の超高真空を構成する機器全てをアルミニウム 合金化するととに成功しており，乙れらの応用製品をカタログ商 品として購入するととが可能になりつつある。

§ 2. 加速器のアル

加速器の真空装置の一部をアルミニウム合金化しょうとした最 初の試みは西独ハンブルグにあるDESY 研究所であった。 DESY では 6 年前にPETRA [ $19 \mathrm{GeV}$ の電子・陽電子衝突型 加速器で現在でもこの種の加速器で世界最高エネルギー了の建設 を始めており，真空チェンバーにアルミニウム合金の型押出し材 を利用していた。１０）アルミニウム合金採用の理由は高エネルギー電子が磁場で偏向される際に 発生する強力なシンクロトロン放射に伴う真空チェンバーの発熱を冷却しなければならなかった からである。アルミニウム合金の熱伝導の良好さが買われたのである。とてろがアルミニウム合 金の真空チェンバーを接続するフランジや,ベローズなどは従来のステンレス鋼を利用していた。 従ってDESY 研究所ではアルミニウム合金とステンレス鋼を接合する高度な技術を必要とし,そ の開発を強力に進めていた。PETRAの後に続いて建設された米国のPEP ${ }^{11}$ [ [ スタンフォー ド線型加速器センターの $18 \mathrm{G} \mathrm{eV}$ 電子・陽電子衝突型加速器 $]$, 高エネ研のPF ${ }^{12)}$, 現在建設 中の米国NSLS ${ }^{13}$ [ $[$ ブルックヘブン国立研究所の $2.5 \mathrm{GeV}$ 放射光源施設]は全て西独の DESYのアルミニウムとステンレスの接合技術を利用している。

§3. なぜ全てアルそニウム合金か？

§2で述べたようにてれまでの流れは西ドイッの技術の応用であるが,トリスタン計画ではて れまでと全く異った発想で全てアルミニウム合金による超高真空系を建設しようというものであ る。何故に全てアルミニウム合金とするのかについて述べる。シンクロトロン放射に伴う真空チ ェンバーの発熱を冷却効率の良いアルミニウム合金で行うととと決めた場合，西独のようにフラ ンジやベローズをステンレス鋼とすると，超高真空を達成するのに不可欠の加熱脱ガス処理でア 
ルミニウム合金の耐熱性の不足から $\left[\right.$ 約 $150^{\circ} \mathrm{C}$ を限度とする $]$ ステンレス鍊の加熱脱ガス処理 が充分行なえずステンレス鋼の放出ガスがシステムの到達圧力を制限するという不都合を生ずる。 アルミニウム合金とステンレス鋼の接合は大きさ，形状あるいは用途により爆発接合，TIG 溶接， 摩擦圧接, 14 ） ロール圧接，拡散接合などの方法を組合わせるが，いずれも接合面に銀やニッケル あるいはチタンなどの異材を中間材としたり，特殊な前処理をするなどの工程を必要とし，構成 が複雑となり，信頼性に欠け，且つ高価となる。

東北大学原子核理学研究施設の $270 \mathrm{MeV}$ 電子線型加速器でてれまでステンレス鋼のフランジ 接合部にビームハンドリングの際，ビ一ムを当ててしまうとビーム損失による発熱に伴う局所的 歪みのためメタルシールから気密漏れを生じるととが問題となっていた。アルるニウム合金では ステンレス鋼に比較して熱伝導が約 15 倍良好なため局所的な加熱に対しても熱の分散のため歪 みを最少限にとどめ気密漏れを起としにくいと推定し，アルミニウム合金とステンレス鋼の同一 形状の真空チェンバーを用いて比較実験をしてみた。 ス䤡では極めて短時間で気密漏れを起すのに対し、アルミニウム合金では気密漏れを起てさない。 ての場合ステンレス鎆ではビームスポットのみ局所的に高温に達しているが，他は手を触れるて とが出来るのに対し，アルミニウム合金では気密漏れを起とさないため長時間ビーム照射を行い 真空チェンバー全体がはぼ均一に熱くなる。いずれの真空チェンバーも冷却を行っていない。冷 却を行った場合でもステンレス鋼ではビームスポットは高温になり，アルミニウム合金ではほと んど熱くならないという差になって現われる。

電子ストーレジリングの場合は陽子シンクロ トロン程, 残留放射能に困らないが，フランジ などをステンレス鋼とすると作業の集中する部 分がステンレス鎆では放射能の被爆の低減に寄 与しない。

§4. 新開発の全てアルミニウム合金の超高真空シ ステム

\section{1 フランジ継手}

開発された全アルミニウム合金超高真空シス テムは従来のステンレス鋼のコンフラットフラ

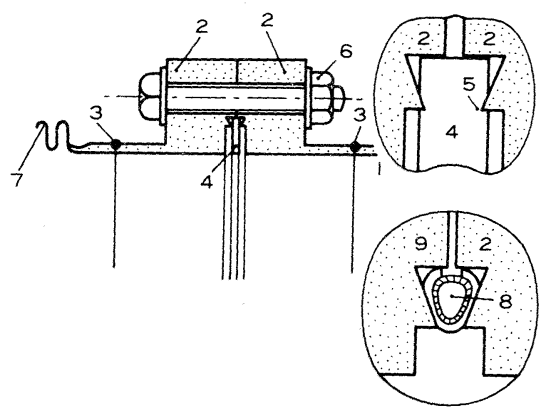

1. パイプー6063-T6. 2. フランジー2219-T87. 3. AC-TIG (DCSP-TIG) 溶接。4. ガスケットー1050-HI8，5. CrN (TiN) コーテング. 6. ボルトー2024-T4.ナットー6061ーT6. ワッシャ -2017-T3. 7. ベロースー5052 (3004). 8. ヘリコフレックス 9. ステンレス鑟コンフラットフランジ。

第 3 図 アルミニウム合金超高真空フランジシステム。 
ンジと組合わせても使える所謂コンパチブルシステム ${ }^{16)}$ である。図 3 コンパチブルシステム とした理由はアルミニウム合金システムが発展の途上にあり, 場合によってはステンレス鋼で作 られた汎用の超高真空機器 [ 質量分析器など]を利用せざるを得ない。フランジ継手はアルミニ ウム超合金 2219 -T 87 材を用い, 形状はコンフラットフランジとはとんど同じである。気密 シール部のナイフエッジは特にダィアモンドバイトによる鏡面仕上げとしている。ヘリコフレッ クスを利用する場合，鏡面仕上げの面との組合わせで望ましい気密特性が得られる ${ }^{17 \sim 18)}$ とと, 気密シール面の管理の容易さなどのためである。気密シール部へのスクラッチ傷が原因となる真 空漏れ，および高温締付けによるガスケットの接着を防ぐなどのためフランジ表面にはイオンプ レーテング法 ${ }^{19 〜 20)}$ による $\mathrm{CrN}$ ，またはTiNコーテング処理を行っている。コーテンク膜厚 は約 $3 \mu \mathrm{m}$ で, 膜の硬度は $\mathrm{Hv} ： 1500$ 以上が得られている。フランジ材の $2219-\mathrm{T} 87$ はス テンレス鋼とほぼ同等の機械的強度を持ち[表 1$]$, アルミニウム合金では最高の高温強度を持 つ。ての合金はJIS 規格には無く，米国の宇宙ロケットの液体然料タンクに大量に使われたことが あるが，真空フランジへの応用は初めてである。現在国内数社で製造している。量産によるコス

表 1 アルミニウム超合金 2219-T87 とステンレス鋼の機械的性質の比較

\begin{tabular}{lcrr} 
& & $2219-T 87$ & SUS -304 \\
\hline Ultimate Strength & $\mathrm{kg} / \mathrm{mm}^{2}$ & 49 & 56 \\
Yield Strength & $\mathrm{kg} / \mathrm{mm}^{2}$ & 40 & 26 \\
Modulus of Elasticity & $\mathrm{kg} / \mathrm{mm}^{2}$ & 7500 & 19700 \\
Brinell Hardness & $10 \mathrm{~mm} / 500 \mathrm{~g}$ & 140 & 145 \\
\hline
\end{tabular}

卜低减, 溶接工程の低减, 有効口径を最大にするなどの目的で型鍛造によって［図4]に示され るフランジを作っている。むろんめくらフランジも型鍛造による。ガスケットはアルミニウム合 金 1050 -H 18 の磨を板材からプレス法で製作したものを利用する。ボルトはアルミニウム 合金 2024-T 4 にアルマイト処理したもの，ナットは6061ーT 6材を, ワッシャは2017 一 T 3 材に硬質アルマイト処理したものを用いる。ボルト・ナッ・ワッシャの組合わせを脱脂状態で 50 回のくり返し締め付けに対し，一定締め付けトルクで一定の軸力を発生する。

\section{2 ビームチェンバー}

加速器の真空チェンバーは単に円型パィプというのは希で, 冷却パイプ, ヒーター溝, さらに 


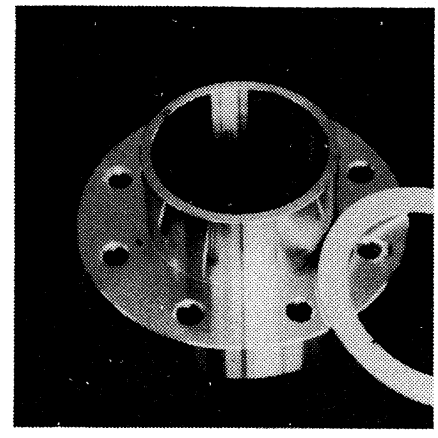

第 4 図 型鍛造による溶接タイプの アルミ合金フランジ。

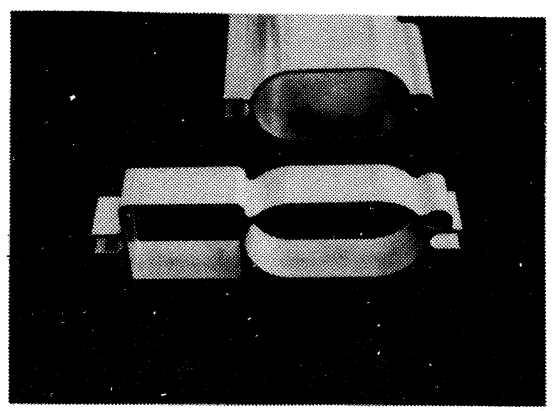

第 5 図 押出しによって作られたトリスタンの偏向 (手前) および四極マグネットへ組込む真空チェンバー。

はポンプ室などの機能を備えた複雑な断面形状［図５］となる。複雑な断面形状のパイプはアル ミサッシの型押出し法と基本的には同一の方法で作られ，材質もはば同じ 6063-T 6 合金であ る。特に超高真空用材料として亜鉛などの不純物を極力抑える，表面を出来るだけ平滑に，さら に特殊な工程で油分や水分の吸蔵された酸化層を抑えて清净な内表面を作るなどの工夫を行って いる。

\section{3 ベローズ}

機械的歪み，加熱脱ガス処理に伴う熱伸縮を吸収するためアルミニウム合金 5052 又は 3004 材を用いた液圧成型ベローズ 21 ) 利用出来る。ベローズ部分は伸縮性を持たせるため薄肉が 不 可欠である。とてろがベローズと厚肉のパイプあるいはフランジと溶接接合する場合，溶接性が 極端に悪くなる。この困難を解决するためにベローズの素管の段階でベローズに対応する部分を 薄肉に, 両端の溶接接合する部分は薄肉部分からゆるやかに厚肉としてから夜圧成型を行う。乙 の方法で円型はもちろん長円型[図 6] のベローズも作られ, 自由長の士10\%の伸縮のくり返 しでは $10^{4}$ 回をクリアする寿命を得ている。最近ではベローズの端部が薄肉でも電子ビーム溶 接で良好な接合が出来る。

\section{4 十字, T字，L字などの配管}

配管やバルブなどに必要な十字管，T字管，L字管などはステンレス鋼システムでは溶接構造 となっているが，アルミニウム合金は展性などの加工性が良好なためバルジング加工 ${ }^{22}$ によっ 
て一体構造に作ることが出来, 量産によって低コス ト化が計られる。

\section{5 イオンポンプ}

ストーレジリングでは $10^{-9}$ Torr 以下の超高真 空を要求されるので, 偏向マグネットの綎磁場を利 用して組込型イオンポンプを主ポンプとする。通常 イオンポンプはチタン板のカソード, ステンレス鋼

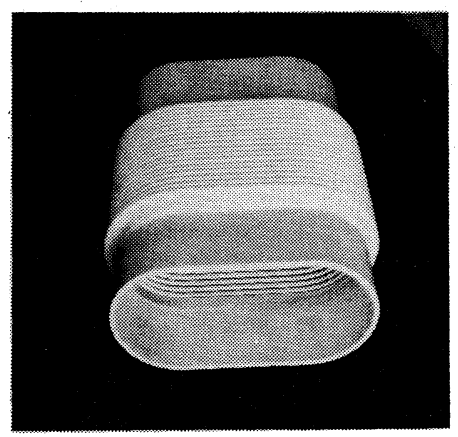

第 6 図 長円断面のアルミニウム成型へローズ。

のアノードや枠で電極が構成されているが，アルミ

ニウム合金の真空チェンバーにとのイオンポンプ素

子を組込んでも良好な超高真空特性が得られない。理由は既に述べたが，アルミニウム合金の耐

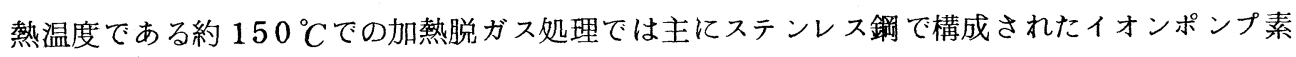
子の脱ガス処理が充分行なえない。そてでカソードのチタン以外をアルミニウムに置き換え，且 つアノードの構造を円筒型から積層型 ${ }^{23)}$ とした。さらにチタンも板状から棒状に変更した。 [図 7 ] その結果 $150{ }^{\circ} \mathrm{C}$ と，24時間の初期加熱脱ガスのみで $10^{-1}{ }^{\circ}$ Torr 台の超高真空が極 めて短時間に得られるようになった。一般にカ ソードは真空チェンバーと同一電位になってい るが，乙の組込型イオンポンプのカソードは電 気的に絶縁されている。このためペニング放電 の電流のみ高圧の絶縁物の漏洩電流と分離して 読み取るととが出来, $10^{-9}$ Tor r 以下の超高 真空領域まで圧力とポンプ電流が比例関係にあ り超高真空ゲージの役目をする。10-10 Tor r 以下では冷陰極放電によって比例関係が破れる。 通常のイオンポンプも組込型イオンポンプと ほぼ同様の電極構造と材料とした。違いはカソ 一ドを板状としたが島状に穴明き構造[図8] とし，且つ電気的絶縁をしなかったととである。
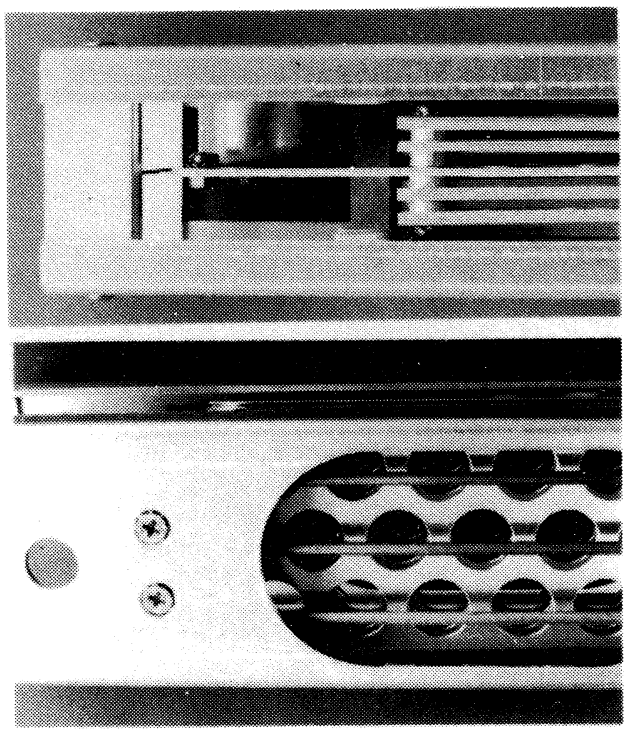

第7図 組込型イオンポンプ。 イオンポンプのケースは特殊押出しのアルミニ 
ウム合金 6063 -T 6 を利用した。乙れま で $301 / \mathrm{s}$ と $5001 / \mathrm{s}$ の 2 種類を実用化 している。押出しによって作られたイオンポ ンプケースにはヒーター溝が設けられ，アル ミニウムシースヒーターが埋め込まれ保温材 を用いず $150^{\circ} \mathrm{C}$ の有効な加熱脱ガス処理が 出来る。局所的なと一タ一加熱のみでほぼ均 一の加熱が出来る。

\section{6 ターボ分子ポンプ}

主排気系のイオンポンプの粗引き用として ターボ分子ポンプを利用する。ターボ分子ポ ンプのローター，モーターハウジングなどは 既にアルミニウム合金化されていたがフラン ジやボディもアルミニウム合金に置き換えた。

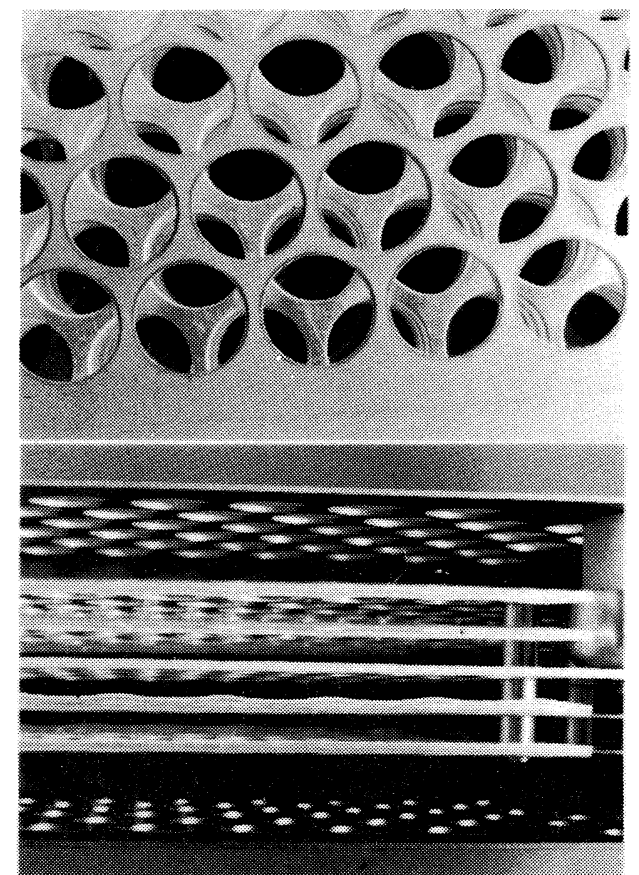

第8図イオンポンプの構造。 この結果 $100{ }^{\circ} \mathrm{C}, 24$ 時間の初期加熱脱ガス 処理のみで極めて短時間に $10^{-9}$ Torr 以下の超高真空が得られる。

\section{7 バルクゲッターポンプ}

非蒸発型バルクゲッターポンプカートリッジをアルミニウム合金フランジに組立てた。電流導 入端子は後で述べるアルミニウム合金とアルミナ磁器を気密封止したものを用いる。活性化の際 カートリッジは $700^{\circ} \mathrm{C}$ 高温となるが, 真空チェンバーやフランジをアルミ合金化すると自然 放冷のみで水冷を要しない。

\section{8 全アルミニウム合金自動ゲート弁}

巨大なストーレジリングを真空的に分割するととは, 組立, 維持, 改善などの効率をよくする 意味で極めて重要である。電子ストーレジリングのゲート弁としては。全てアルミニウム合金とい う要求の他, ビームインピーダンス整合のため長円開口部を持ち且つゲート弁が開いた状態でビ 一ムに伴う壁電流を滑らかに流す構造とするなどの笽しい要求がある。乙れらの要求を満たすた 
め中間排気付, 二重鏡平面シール方式 ${ }^{7,24)}$ [図9]採用した。

図に示されるようにゲート弁の中間に遠隔操 作可能な仕切板があり，ての仕切板にはめく らの部分と長円の開口部とがある。ゲート弁 ボデイには 2 組の中空の 2 重ベローズがあり 遠隔操作で伸縮される。中空, 長円の 2 重べ ローズの仕切板に面した端部は極めて薄いア ルミニウム合金のダィアフラムとなっている。

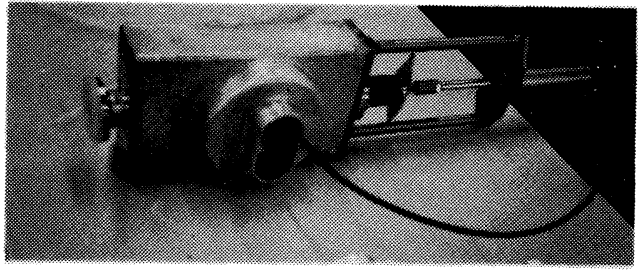

第 9 図 中間排気的, 二重鏡平面シール方式ゲート弁。 仕切板表面はダイアモンド切削で超鏡面処理 がなされ，且つイオンプレーテング法によるC rN コーテング処理がなされている。ダイアフラム もほぼ鏡面に近く，両者は圧縮空気で圧接され気密シールを可能とする。てれまでの最良の気密 性は中間排気のポンプとして $51 / \mathrm{s}$ の時, 全リーク量は $10^{-10} \mathrm{Torr} \cdot 1 / \mathrm{s}$ 以下となり，悪 い場合でも $10^{-8}$ Torr・1／s 以下となっている。

\section{9 全アルミニウム半自動 L 型弁}

主に粗引系と超高真空系を分離するためのバルブとして全アルミニウム半自動L型弁を用いる。 バルブボデイはバルジング加工で一体構造となっている。気密シール部はアルミニウムのヘリコ フレックスを利用する。弁座および弁体は $5^{\circ}$ および $15^{\circ}$ の傾斜をもち，どちらの気密シール面

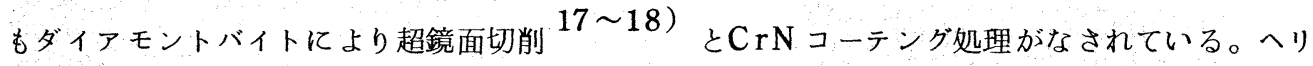
コフレックスは弁座に固定されている。ベローズはむろんアルミニウム合金である。気密特性は $150 \mathrm{~kg}-\mathrm{cm}$ の一定トルクの締め付けで $10^{-10}$ Torr ・1/s以下の封止を 100 回以上保つ。 てのバルブはターボ分子ポンプの上に組込まれるので不意の停電時, 緊急遮断弁として作動する ととが要求されおもりを市り下げたテープを軸に巻きつけたフライホイールの回転力を利用し て自動化している。開く場合はあえて手動で行なう。ICF-70,114,および152の3タイプ が利用出来る。

4.10 アルミニウム合金とセラミックの気密封止

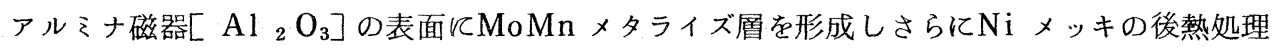
を行う。アルミニウム合金 3003 ととのメタライズされたアルミナ磁器を真空中でA1 - Si - 
$M g$ 万うを用いて真空ろ方付忖を行う。乙の基本技術を応用して多様な真空端子 ${ }^{25}$ ）セラミックチ エンバー，さらにサファイア $\left[\right.$ 単結晶の $\left.\mathrm{Al}_{2} \mathrm{O}_{3}\right]$ の空 ${ }^{26)}$ を作るととが出来る。てれまでコバ 一ルを用いた真空端子BNCシリーズ，Nシリーズ，SMA，SHVなどの同軸端子，22 pin，

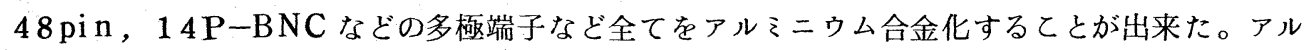
ミニウム合金の各種真空端子は電子ビーム溶接によってアルミニウム合金フランジへ良好な接合

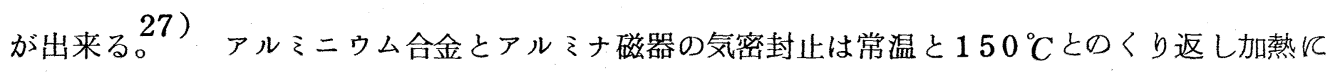
耐える。小型のものならば常温から液体䇪素へ落下投入しても割れない。

ストーレジリングへのビーム入射・取出しのための早い立上りのパルスマグネットへ組込まれ るセラミックチェンバーも真空ろう付けによって両端にアルミニウム合金 3003 で作られたパイ プを接合し，ビームパィプと自動溶接で接合する。セラミックチェンバーの端部のパイプはベロ ーズと同じ発想でろら付け部分は薄肉に，厚肉パィプとの接合部分は厚肉となっている。

\subsection{1 真空ゲージ}

超高真空ゲージはアルミニウム合金とセラミックで気密封止された $14 \mathrm{P}-\mathrm{BNC}$ 真空端子に組 立てられ，真空端子はアルミニウム合金フランジに電子ビームで溶接接合される。[図 10 ]中高 真空ゲージとして逆マグネトロンゲージを利用している。てのゲージもフランジ，ボディ，内部 電極，同軸真空端子を全てアルミニウム合金としている。［図11]

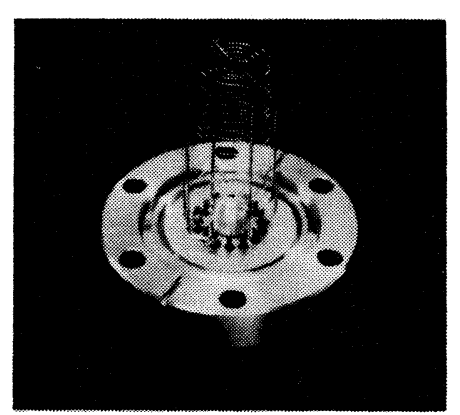

第10図 アルミニウムフランジに組立てられた B-Aゲージ。

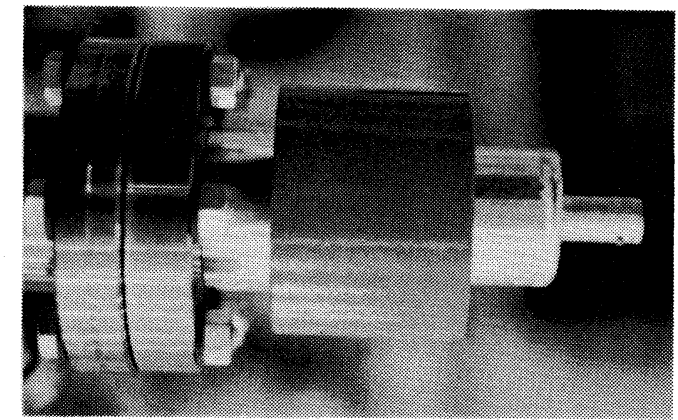

第11図 アルミニウム合金で作られた逆マグネトロンゲージ。

4.12 真空スイッチ

コンピューターコントロールの場合, 超高真空かはとんど大気圧かを判定するために大気圧と 50 Tor r の間で接点信号を出す真空スイッチを必要とする。アルミニウム合金フランジに片端 
が閉ビたアルミニウム合金ベローズを電子ビーム溶接で接合する。ベローズの端部にマイクロス イッチをつける。

\section{13 ガス導入弁}

超高真空から大気圧にする場合次回の排気時間を節約し且つ加熱脱ガ ス処理を最少限にするた め純酸素を導入する。乙の場合のガス導入弁も全てアルミニウム合金のものが利用出来る。

\subsection{4 直線駆動装置}

ビーム計測などに直線駆動装置を必要とする。運動用ベローズとしての要求を満たすアルミニウ ウム合金ベローズに関して現在でも種々の試みをしているものの残念ながら成功していない。従 つてステンレス鋼の溶接ベローズをアルミニウム合金とステンレス鋼の爆着や摩擦圧縮によるト ランジション材を利用してアルミニウムへ変換している。その他は全てアルミニウム合金を用い ている。

\section{15 加熱ヒーターと断熱保温材}

超高真空を達成するため効果的な加熱脱ガス処理が要求され， $150^{\circ} \mathrm{C}, 24$ 時間の加熱を行う。 アルミニウム真空チェンバーにはあらかじめヒーター溝を設けておく。10 1050 材で作られたシースに非磁性材のコイル状 $\mathrm{Ni}-\mathrm{Cr}$ 発熱体をマグネシア粉末で電気的に

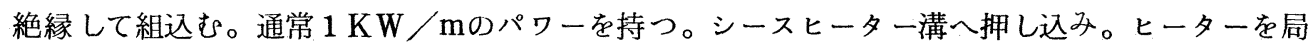
在させて出来るだけ均一の高温に保ち，且つ電力を節約するため断熱保温材で包むのが望ましい。 加速器ではマグネットや電力のコストを低くするため真空チェンバーと磁極の隙間を最少にした いので出来るだけ薄肉で断熱保温効果のある断熱材を要求される。耐熱性のあるカプトンフィル ム[ $25 \mu \mathrm{m}$ 厚み $]$ の両面に〜 $1 \mu \mathrm{m}$ 厚のアルミニウム蒝着膜をつけさらに熱間ロール加工で 凹凸処理したものを積首巻きとして利用する。伝熱の 3 要素を効果的に抑え極めて薄い断熱層で 目的を達するととが出来る。

\section{§5. アルミニウム合金材料}

アルミニウム合金は製法によって展伸材と鋳物材に大別され，それぞれ非熱処理合金と熱処理 合金に分けられる。 ${ }^{28)}$ 現在のところ鋳物材は超高真空材料に不向きである。非熱処理合金は Mn , 
$\mathrm{Si}, \mathrm{Fe}$ ，及び $\mathrm{Mg}$ などの硬化に寄与する元素を単独または組合せで添加し 1000 (純アル ニウム)，3000( $\mathrm{Al}-\mathrm{Mn}$ 系)，4000( $\mathrm{Al}-\mathrm{Si}$ 系)及び5000 ( $\mathrm{Al}-\mathrm{Mg}$ 系) シリ 一ズ合金と呼ぶ。とれらの合金は加工硬化によって強度が増大するのでHの質別記号とそれに続 く数字でその程度が示される。熱処理合金は $\mathrm{Cu}, \mathrm{Mg}, \mathrm{Zn}$ ，及びSi などを単独または組合せ で添加し, 合金の初期強度を增し,さらにてれらの元素や化合物は温度上昇とともに固溶度が増 すので，焼入れ，焼もどしなどの熱処理により強度も著しく増し，2000（ $\mathrm{Al}-\mathrm{Cu}$ 系）， 6000 ( $\mathrm{Al}-\mathrm{Mg}-\mathrm{Si}$ 系) 及び 7000 ( $\mathrm{Al}-\mathrm{Zn}-\mathrm{Mg}$ 系) シリーズ合金と呼ばれる。乙 れらの合金は質別記号 $\mathrm{T}$ とれに続く数字により，熱処理の種類が示される。多くの熱処理合金 は焼入れ後 1 週間程度の常温時効で強度が増し安定する。 $\mathrm{Mg}$ と Si または Mg と Zn を含む合金 は長期にわたり時効硬化が続き, 比較的高温で適当な時間加熱（人工時効, 焼もどし）を行うと 強度はより増大し安定する。また溶体化, 焼入れ, 冷間加工および高温時効を適当に組合わせる と更に強度を増す。とのようにシリーズの違い, 質別の違いで機械的特性, 加工性, 溶接性, 而 食性, 耐熱性などが大巾に異なるばかりでなく, 超高真空材料として重要な放出ガス率に関して 微量元素, 圧延や押出しの工程, 保存状態, 表面処理などで大巾に異るので単にアルミニウムと して対応すると失敗する。

\section{11000 シリーズ}

$99 \%$ 以のアルミニウムを含むものをいう。特長は優れた耐食性, 高い電気伝導・熱伝導度, 優れた加工性を持つ反面著じるしく機械強度が低い。超高真空材料としてはイオンポンプの電極 などに利用される。

\subsection{0 シリーズ}

$\mathrm{Cu}$ を主要添加元素とし, 溶体化処理を必要とする。焼入れ常温時効後は軟鋼と同等以上の機 械強度を持つ。一般に $\mathrm{A} 1-\mathrm{C} \mathrm{u}$ 系合金は耐食性, 溶接性が劣るが, 高強度, 而熱性, 低温での 特性などに優れている。宇宙航空の分野で溶接性などの改善がなされ，2014，2024,2219 などの超合金が使われている。特にフランジに用いられる2219 合金はCu t比較的多く加え， 低融点多元共晶成分を形成しないようにMg およびSi の量を抑え, 結晶粒の微細化のため Mn を加え,さらに結晶粒の微細化のため $\mathrm{Ti} ， \mathrm{Zr}$ ，およびV を添加している。調質として溶体化， 焼入れ, 命間加工および高温時効を行いアルミニウム合金では最高の高温強度を持ち, 且つ溶接 
性が良好，低温特性にも優れるなどフランジ材料として最も適当な合金と言える。

\section{33000 シリーズ}

$1.5 \%$ Mn を添加すると純アルミニウムの耐食性を損うととなく強度が増す。3003はアル こニウム真空ろう付けと最適である。更に強度の向上と加工性を図ってMgを添加した 3004 はべ ローズに最適である。

5. 44000 シリーズ

アルミニウムに多量の Si を加えると, 合金の融点を下げるととが出来るので 4043 はT IG 溶接の溶加材として用いられる。真空ろら付けとはMg をゲッター材として添加した 4047 用いる。

\subsection{0 シリーズ}

アルミニウムに Mg を単独あるいは Mn とともに添加すると強度の向上に有効で加工硬化によ ってさらに強度を増す。耐食性, 溶接性も良好で一般の溶接構造用合金としては最もょく使われ ているが, 超高真空材料としては加熱脱ガ ス処理が不可欠であるてとから, 応力窗食割れ, 耐熱 性に難点がある。但し加熱脱ガス処理をしない真空系では使える。

\section{66000 シリーズ}

$\mathrm{Mg}_{2} \mathrm{Si}$ を形成するように Mg 及び $\mathrm{Si}$ を添加した熱処理合金が比較的強度があり，耐食性， 成形性特に押出性に優れており, 比較的耐熱性もあり, 超高真空用の押出し材に最適であり $6063 ， 6061$ などが用いられる。

\section{77000 シリーズ}

この合金は一般に高力合金の皮材として用いる7072, 強度に重点をおいた 7075 ，溶接性な ぞも改善した 7001 などに分けられる。7075は航空機に多用される超合金でアルミニウム合金 のなかで最高の強度を持つが, 耐熱性, 溶接性に難点がありまたZn を多く含むので超高真空材 料としては多分適当ではない。現在超高真空材料としての可能性を調べている。駆動装置,バル ブの軸などの構造材として超高真空に面しない部分に 7075-T 6 を多用している。 以上材料について概説したが，JIS 規格では微量成分まで規制しておらず，場合によってはク 
ズ材を混入した再生材料を知らずに利用してしまうととのないよう注意を要する。超高真空 材料は，バージンの素材から製造した素性の明白な材料を用いなければならない。ミルシート [ 成分分析表]の提出を求めることが出来る。フランジ材料は複雑な熱処理で優れた特性を得て いるので, 後の加工や溶接などの熱影響で T 87 の調質が失われる場合もあるので充分アルミニ ウムの特性を理解して対応しなければならない。フランジの型鍛造では金属組織の流れの方向も 調整してある ので単に丸棒や厚板を利用するのには問題がある。型押出しの真空チェンバーは 基本的には空枠のアルミサッシと同じ製造方法であるが，もし同一の製造工程で作られた押出材 で超高真空をねらっても目的を達するととが出来ない。ステンレス鋼に優る放出ガス特性を持つ 特殊押出し材は, 押出しの際パイプの内表面を完全に大気から遮断する。 30 ) また後の焼もどしも 大気と遮断した状態で行う。通常の方法では内表面に厚い酸化変質層が生成され大量の油分や水 分などの污れを吸蔵しているのに対し，新しい方法では清净で緻密な薄い酸化層で覆われた超高 真空材料として望ましい表面をもつ。圧延板材も表面は酸化変質層が油分で污れていると思わな くてはならず，適当な方法で除去しなければならない。

材料の入手や保管には油分や水分で污さない，材料名を明記する[目視では材料を区別出来な い了，傷をつけないなど注意を要する。出来れば信頼出来る入手ルートを確立するてとがよい。

§6. アルミニウム合金の溶接

アルミニウム合金の超高真空への適用で材料と並び溶接 ${ }^{31 \sim 34)}$ の問題がある。ステンレス 鋼の溶接と比較してアルミニウム合金の溶接は難しい。それは (1) 約 10 倍以上の熱伝導度をもち 熱の分散が大きく溶融温度になり難く且つ広範囲に熱影響が現れる。従ってパワー密度が大きく 要求され, 溶接のパワー密度の適正条件の変動が大きい。（2)溶融潜熱が 1.5 倍大きく，低融点 にもかかわらず大きい入熱が必要になる。とのため溶融プールが大きくなる。 (3) 線膨張率が 2 倍以上大きく薄板と厚板の溶接では歪みが大きくなる，場合によっては割れを起とすととがある。 (4) 溶融金属の表面張力が約 $1 / 2$ と小さいので, 溶融プールが垂れ下り易いので上向き姿勢では 特に困難がある。（5) 表面に強固な酸化皮膜が存在し，母材同志あるいは溶加材との融合を妨げ たり，溶融金属中に残留して浴接欠陥になり易い。（6化学的に活性で表面は酸化膜が出来，ま た溶融金属は水素を溶解吸収する。溶接中に溶解した水素は溶融金属の凝固速度が速いことから ブローホール (空胞) として残留する場合があり, 気密漏れや, 継手強度の低下となる。（7) 熱 処理合金あるいは加工硬化材料の場合，溶接の熱影響によって母材の機械的性質が劣化する。 


\section{1. 溶接法}

超高真空材料の溶接法として通常 TIG 溶接が用いられ，0.7 m m 以下の薄板では電子ビーム 溶接を応用し，10 $\mathrm{mm}$ 以上の厚板ではMIG 溶接が利用される。[図 12 ]
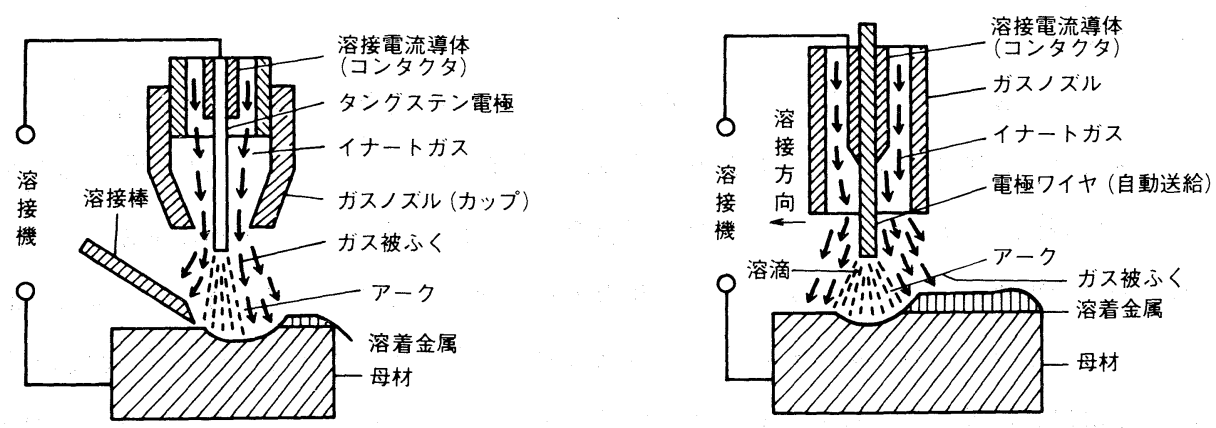

第12図 TIG 溶接（左），MIG 溶接（右）の概念図。

TIG 溶接はアルゴン・ヘリウムなどの不活性ガス雾囲気でタングステン電極と母材との間にアー ク放電を発生させ, そのアーク熱で母材, 溶加材を溶融して接合する。T IG 溶接には, 交流法 ( A C - T IG ), 直流正極性（DSCP－TIG），および直流逆極性（DCRP-TIG）がある が，アルミニウム合金の溶接では AC-TIG が多用される。 AC - T IG 法はアルミニウム表面 の酸化層をアルゴンイオンで吅き酸化層を除去するクリーニング作用があるので比較的溶接欠陥 が少ない。アーク長が大きいので手動溶接の操作性が優れている。しかし溶接ビード幅が质い, 融 け込みが浅い，歪みが大きいなどの欠点がある。

DCSP - TIG 法は狭いビーム幅, 深い融け込みが得られ歪みが小さい溶接法であるが, 酸化 層を除去するクリーニング作用がなく，アーク長が短く手動は難しい。トリスタンのビームパィ プは自動溶接で接合されるが，ょり高品質の溶接接合とするため A C - T IG とD CS P - T IG の 長所を取り入れたパルスDCS P - TIG 法を採用している。クリーニング作用をもたせ，狭く深 い溶接ビードが得られ, 歪みも少なく, アーク長の短かいととも自動走行機構, アーク電圧調整 器で補っている。むろん溶加材も自動供給である。

$0.7 \mathrm{~mm}$ 以下のベローズや真空端子をTIG 溶接では現在のところ良好な接合が出来ない。真空 中の電子ビームではあらかじめ表面の酸化層を除去しておけば溶接中に酸化や水素の吸藏は抑え られパワ一密度の大きい入熱で極めて短時間で熱影響や歪みの少ない良好な溶接が出来る。通常 電子ビーム溶接では急速入熱, 急冷のため割れを生じるてとがないので溶加材を用いない。

MIG 溶接は不活性ガス雾囲気中で連続的に供給される電極ワイヤーの先端と母材の間にアーク 
を発生させ電極ワイアーを溶融させながら溶接を行う。直流逆極性 (DCRP) が用いられ，クリ 一ニング作用があり，深い融け込みで，溶着量が多いので大型厚肉真空チェンバーに適合する。

\section{2 熱影響}

ステンレス鋼に比較して熱云導が良好なため溶接部分に広範囲に熱影響部を生じ，冶金的な不 連続部となり，継手強度が低下したり，耐食性が損われる。熱影響怯非熱処理合金と熱処理合 金とでは本質的に異なる。非熱処理合金の加工硬化材では母材の再結晶温度以上に加熱さ れた領域で軟化が生じ，母材の固相線温度以上に加熱された領域では溶接条件によっては結晶粒 界が溶融する。熱影響部の幅や軟化の程度は母材の調質や入熱によって異なる。熱影響部の機械 的強度は母材の軟質材 $[$ 質別，0]にまで低下する。熱処理合金の熱影響部はさらに複雑で溶融 領, 融合域, 固溶域, 過時効域, 母材と続く。融合域は母材の固相線温度以上に加熱されて粒界 が局部的に溶融した領域，固溶域は第 2 相が固溶するに充分な温度に加熱された後急冷され固溶 体を保っている領域でどちらの性質も母材と比較的似ている。過時効域は軟化を伴うが非熱処理 材のように軟質材にまで強度の低下を生じるととはない。通常熱処理合金の余盛のままの溶接継 手の引張試験を行うと過時効域で破断し, その継手効率は $40 \sim 70 \%$ でる。溶接後再熱処理 をすれば $80 \%$ 以上の継手効率に回復する場合もある。

\section{3 溶接欠陥と防止}

アルミニウム合金の真空チェンバーの溶接欠陥 33 )
接割れ,
(2) ブローホールであり，
(3) 融合不良,

で最も困るのが気密漏れに結びつく

(1) 溶

溶接割れは主に溶接部に生じるが，熱影響部に生じるとともある。割れは溶融金属が凝固時に 起る割れと，熱影響部に生ずる局部溶融による微少割れに分けられる。凝固時に起る高温割れは 2 元あるいは擬 2 元共晶合金系において液相線 と固相線の間の温度範囲の広い程生じ易い。従っ て合金の化学組成に影響されるので母材と溶加材の適正な組合せとしなければならない。ビード の割れは溶接部のすき間が広い場合や, 縁継手や角継手などの隅肉継手で溶着量が少なくビード 形状が偏平か四形になる時に生じ易く開先設計を適正としなければならない。［図13］に開先 の代表例を示す。溶接終了部のクレーターでは最終凝固部を中心にして放射状に割れが生じるて とが多く, 溶加材を多く供給して余盛をしながら除々にアーク電流を降下させるなどの注意を要 する。 

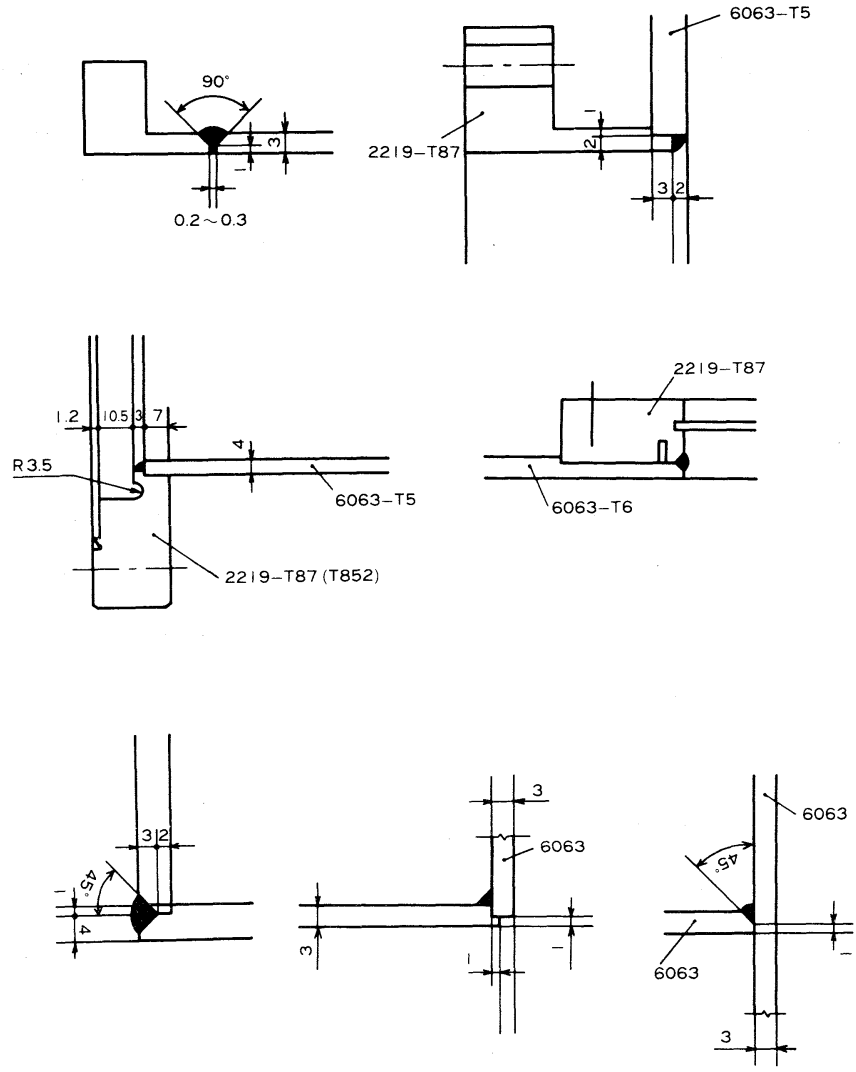

第13図 代表的なアルミニウム合金の溶接開先形状。

アルミニウムは溶接凝固に際して水素の溶解度の変化が著しく，水素がブローホールの支配的 な原因とされている。ブローホールとなる水素は母材や溶加材の内部ガス, 表面の污れ, 不活性 ガスに混入されているものの他, 雾用気の水分の分解が原因となる。従って素性のわかった良い 材料, 溶加材の入手, 油や水分で污れないように管理, 溶接機器の整備, 作業環境を除湿するな どの整備，不活性ガスの管理などに注意を払う必要がある。またブローホールは以上の水素の混 入源を断つととが重要であるが, 開先の設計や溶接姿勢も発生したブローホールが蒸発するよう に考慮する必要がある。

融合不良は溶接開先の形状と溶接条件によって起こることがある。厚肉と薄肉の継手，隅肉・ 角・縁継手で比較的起き易い。アークのねらい位置, トーチの角度が適正でない場合も起き易い。 融合不良は外観上は健全なビードのように見えても溶融池と母材の濡れが充分でなく単にビード 
が母材の上に乗っているのみで気密漏れになるととがある。酸化層の混入は母材や溶加材の酸化 層の除去が充分でない場合に起り, ブローホールの原因, 継手強度の低下になる。原則として母 材の溶接開先は機械加工で酸化変質層を除去する。加工後溶接施工までの保管では酸化が進行し ないように注意する。出来るだけ酸化層除去後すみやかに溶接施工を行うのが望ましい。よく行 われているヤスリ，ワイヤーブラシはかえって酸化層を巻き込むので抑ける方がよい。どうして も機械加工が出来ない場合はハンドカッターで酸化変質層を一皮剥ぐのがよい。溶接のスタート 部に酸化層の影響が出来易いので, 場合によってはクリーニングを充分に行うためトーチを逆方 向に移動させ少し進んだとてろで反転するなどの方法もある。酸化層の混入を防ぎ，ビードの近 傍の母材表面の酸化防止のためトーチからの不活性ガスの他に補助的に不活性ガスを供給したり， 供給したガスが拡散しないようにカバーをつけたり，トーチの逆の側からバックシールドガスを 供給するととは良好な溶接になる。

厚肉では予熱したりするとともあるがかえって酸化変質層を増大させるととがあるので注意を 要する。ステンレス鋼の溶接に比較して溶接電流などの適正条件が狭く，熱影響で時々刻々変化 するので, 出来れば電流制御をする人と溶接作業者が 2 人組になって施工するのが望ましい。い ずれにしても溶接サンプルを作り切断してビードが健全かどうか確認して本番の溶接を行うとと が望ましい。

\section{§7. 超高真空特性}

特殊押出しの方法で製作されたアルミニウム合金管とアルミニウム合金フランジを出来るだけ 油で污さないように端部を機械加工し，TIG 溶接で接合し,リークテスト後,トルエンとエチル アルコールで脱脂洗浄を行う。アルゴンまたは窒素ガスでアルコールを吹きとばし直ちにターボ

分子ポンプで排気すると排気開始後 24 時間で放出ガス率 $\mathrm{Q}_{0} \sim 10^{-10}$ Torr $\cdot 1 / \mathrm{s} \cdot \mathrm{cm}^{2}$ に達する。残留ガスははとんど水で他にわずか水素, 一酸化炭素と二酸化炭素である。この後高 真空のまま $150{ }^{\circ} \mathrm{C}, 24$ 時間の加熱脱ガス排気を続け, 加熱停止後約 8 時間で $Q_{0} \sim 10^{-13}$

Tor $\mathrm{r} \cdot 1 / \mathrm{s} \cdot \mathrm{cm}^{2}$ 以下に達し，アルミニウム合金表面が活性になり，活性ガスを吸着排気する ポンプ作用を持つに到る。排気テストの概念図と結果を[図 14] と［図 15]に示す。ポンプ作 用は特杵押出しのアルミニウム合金チェンバーのみに起とり，従来方法による押出しのアルミニ ウムチェンバーでは起っていない。現在ポンプ作用の解明を進めている。極めて小さい放出ガス 率に達した真空チェンバーに純酸素を注入し大気压にして後, 空気に接触しても加熱脱ガス処理 
なしに短時間で $\mathrm{Q}_{0} \sim 10^{-12}$

Torr $\cdot 1 / \mathrm{s} \cdot \mathrm{cm}^{2}$ 以下の超高 真空を達成出来る表面を保持する。 再び $120^{\circ} \mathrm{C}$ 程度の加熱脱 ガ ス処 理を数時間行うと再び表面が活性 となりポンプ作用が現れる。

$$
5001 / \mathrm{s} \text { のスパッタイオン }
$$
ポンプは常温初期排気のみで 24 時間後に $10^{-9}$ Torr オーダの ほほ超高真空に達し， $150^{\circ} \mathrm{C}$ ， 24 時間 の加熱脱ガス処理で加熱 停止後 $10^{-10}$ Torr オーダーの 超高真空に達する。

§ 8. アルミニウム合金の利点と欠点 アルミニウム合金の超高真空シ ステムは従来のステンレス鋼シス テムと比較して

(1) 放射化された後の減衰が極めて 早い。主にN $\mathrm{N}_{\mathrm{a}}^{24}$ の半減期 15 時 間が勃いている。

(2)良い材料を使えば高真空中で $150^{\circ} \mathrm{C} \cdot 24$ 時間の比較的低 温の加熱脱ガス処理によってガ 放出率 $\mathrm{Q}_{0} \sim 10^{-13}$ Torr $1 / \mathrm{s} \cdot \mathrm{cm}^{2}$ が得られる。また 大気圧に戻して子加熱脱ガスを行 わずにほとんど超高真空が得ら れる。
Q) (QMF)

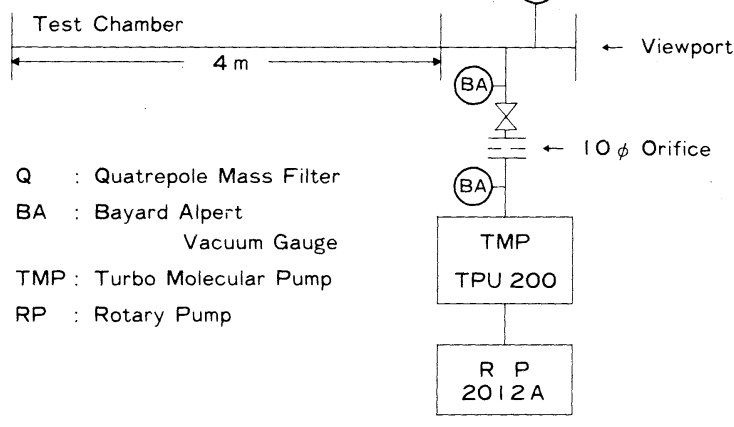

第14図放出ガス率測定の概念図。

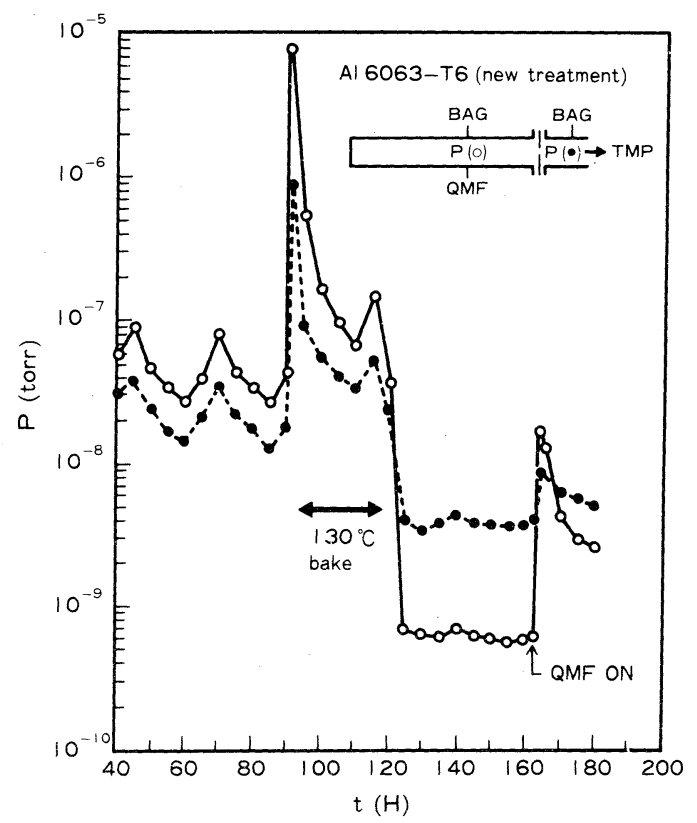

第15四 特殊押出し法によるアルミニウム合金チェンバーの 放出ガス率。 
(3) 熱伝導が良好なため極めて大きな入熱に耐え，局所的な入熱に対しても歪みは小さい。

(4) 完全非磁性。

(5) 合金素材, 調質, 表面処理が選択出来る。

(6) 押出し, バルジング, プレス, ロール, 型鍛造など多様な加工技術が応用出来る。

(7) アルマイト，イオンプレーテングなど多様な表面処理が利用出来る。

（8)極低温での熱変態がなく低温材料としても適合する。

(9)高エネルギ一粒子の透過能が大きい。

(10)軽量・比強度が大きい。

(111)素材，加工など総合的にも低コストとなる。

などの利点 37 がある。

電気伝導度良好に伴う交番磁場中での渦電流効果が大きい，というコイルに応用する場合の利 点が逆になるなど全て長所ではない。てれまで機械強度が充分でない，耐熱性がない，溶接性が 悪い, 放出ガスが多いなどの点で超高真空には不向きと考光られていたのをわずかの可能性の接 点を結びつけて可能にしたわけであるので完全なものではない。従って新しい問題に対して知恵 を出して解决していくしかない。残留放射能の低減にしてもアルミニゥム合金には好ましくない

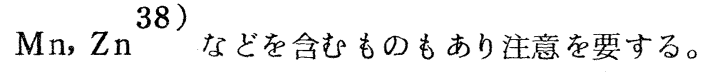

\section{§ 9. まとめ}

世界で初めての全てアルミニウム合金を用いた超高真空系をトリスタン計画に応用し [図 16$]$ ， 昭和 60 年度に予定通り完成すると電子・陽電子衝智型加速器では世界最高エネルギーとなり卜 ップコークの発見を目ざすなど最先端の物理実験が行えると期待されている。残留放射能と超高 真空特性の 2 つを明らかにし，乙れまでわかっていた種々の利点を加え。アルミニウム合金の長

所を加速器ばかりでなく核融合。半導体, 汎用超高真空装置への応用が展開されつつある。 これまでの技術開発は真空を専門としないメーカーとの共同によるもので, アルミニウム合金の 超高真空システムをまとめるには特に材料と溶接のノーハウを充分習得する必要がある。最近真 空メーカー, 重電・重機械メーカーも技術習得に熱心になりつつある。 


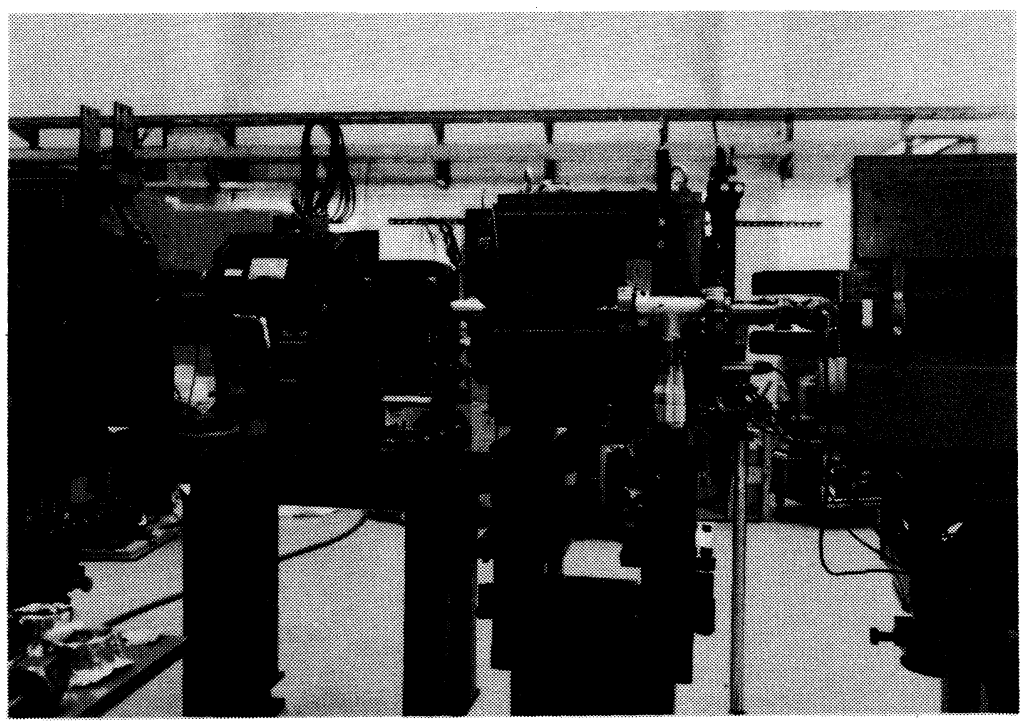

第16図 トリスタン入財蓄積リングの仮組立ての電磁石と真空チェンバー。

参考文献

1）高エネルギー物理学研究所加速器拡充計画，トリスタン I の設計研究，昭和55年 7 月。

2) 石丸, 成島, 水野, 渡部, 久保, 山口, 堀越, 第 4 回加速器及びストーレジリングにおけ る超高真空技術研究会, 高工市研, 昭和 57 年 3 月。

3) 石丸, アルミニウムを用いた加速器の真空容器, KEK-ASN-III, Jan. 1978.

4. H. Ishimaru, J. Vac. Sci. Technol., I 5 (1978) 1853.

5) H. Ishimaru, et al, IEEE Trans. Nuclear Science NS-26 (1979) 4000.

6) 石丸 他, 真空, 22 (1979) 373 .

7) H. Ishimaru, et al, 8 th International Vacuum Congress, Cannes, France, 1980.

8) H. Ishimaru, et al, IEEE Trans. Nuclear Science, NS-28, No.3, 1981.

9) 石丸他, Proceedings of the 3 rd Meeting on Ultrahigh Vacuum Techniques for Accelerators and Storag Rings, 1980, KEK-81-2, 1981.

10) H. Hartwig and J. Kouptsidis, Proc. 7 th Inter. Vac. Congr. Vienna, 1977. 
11) J. R. Rees, IEEE Trans. Nucl. Sci. NS-24, 1977.

12) M. Kobayashi, et al, Nuclear Instrum. Method, Vol. 177, 1980. 111.

13) A. V. Steenbergen, IEEE Trans. Nuclear Sci. NS-26, 1979, 3785.

14）石丸 他, 真空, Vol 21, No.9, 1978, 315.

15）石丸，今野，東北大核理研研究報告，第14巻，第 1 号， 1981.6.

16) H. Ishimaru, 3 rd Symp. Acc. Sci. Technol., Osaka Univ. Aug. 1980.

17）酒井, 石丸, 堀越, 玉井, 真空, 第24巻, 第 7 号, 1981, 408.

18) I. Sakai, H. Ishimaru, G. Horikoshi, Vacuum, Vol. 32, No.1, 1981.

19) H. Ishimaru, IPP-551, Mar. 1982, 219.

20) H. Ishimaru, Proceedings on Ion Assisted Surface Treatments, Univ. of Warwick, 1982, England.

21）石丸, 杉崎, 真空, Vol. 25. No. 4. 263.

22）中村正信，プレス技術，昭和 49 年，第 12 巻，第 $7 \cdot 8$ 号。

23) H. Ishimaru, et al, 8 th International Vacuum Congress, Cannes, France, 1980.

24）石丸 他, 真空, Vol. 25, No. 4, 1982.

25) H. Ishimaru, Vacuum, to be published.

26) H. Ishimaru, Vacuum, to be submitted.

27）石丸, 真空, Vol. 25, No. 4, 172.

28）杉山，溶接学会誌，第48巻 (1979) 第 2 号， 84 .

29）浅胃 他，軽金属学会誌，Vol. 30, No. 7, 1980.

30）塚本 他, 軽金属学会, 1982 .

31）栗山他, IHI技報, 第18巻, No. 1, 昭和53年, 同第16巻，No. 4, 昭和51年。

32）杉山，住友軽金属技報，Vol. 22, No. 1, 2, 1981 .

33）土屋他，IHI 技報，Vol. 21，No. 2, 1981.

34）土屋他, 真空協会 2 月研究例会, 昭和 55 年 2 月。 
35) 石丸 他, 真空, Vol. 24, No. 4, 276.

36) 成島, 石丸, 真空, Vol. 25, No. 4, 172.

37）石丸，アルトピア，第62巻，1982,4月号。

38) 今野, Proceedings of the 4-th Meeting on Ultrahigh Vacuum Techniques for Accelerators and Storage Rings, Tsukuba, 1982, KEK. 82-3.

39) 石丸, 科学朝日, 第 42 巻, No.11.1982.

40) H. Ishimaru, Proceedings of 6-th Symp. on Ion Source and Ion Assisted Technol. Jun. 1982.

41) 石丸, Ionics, Vol. 1, No. 3, 1982. 